\title{
Spiritual Fitness: A New Dimension in Alzheimer's Disease Prevention
}

\author{
Dharma Singh Khalsa \\ Alzheimer's Research and Prevention Foundatio \\ Andrew B. Newberg \\ Thomas Jefferson University
}

Follow this and additional works at: https://jdc.jefferson.edu/radiologyfp

Part of the Integrative Medicine Commons, and the Radiology Commons Let us know how access to this document benefits you

\section{Recommended Citation}

Khalsa, Dharma Singh and Newberg, Andrew B., "Spiritual Fitness: A New Dimension in

Alzheimer's Disease Prevention" (2021). Department of Radiology Faculty Papers. Paper 106.

https://jdc.jefferson.edu/radiologyfp/106

This Article is brought to you for free and open access by the Jefferson Digital Commons. The Jefferson Digital Commons is a service of Thomas Jefferson University's Center for Teaching and Learning (CTL). The Commons is a showcase for Jefferson books and journals, peer-reviewed scholarly publications, unique historical collections from the University archives, and teaching tools. The Jefferson Digital Commons allows researchers and interested readers anywhere in the world to learn about and keep up to date with Jefferson scholarship. This article has been accepted for inclusion in Department of Radiology Faculty Papers by an authorized administrator of the Jefferson Digital Commons. For more information, please contact: JeffersonDigitalCommons@jefferson.edu. 


\title{
Spiritual Fitness: A New Dimension in Alzheimer's Disease Prevention
}

\author{
Dharma Singh Khalsa ${ }^{\mathrm{a}, *}$ and Andrew B. Newberg ${ }^{\mathrm{b}}$ \\ a Alzheimer's Research and Prevention Foundation, Tucson, AZ, USA \\ ${ }^{\mathrm{b}}$ Department of Integrative Medicine and Nutritional Sciences, Department of Radiology, Marcus Institute \\ of Integrative Health, Thomas Jefferson University, Philadelphia, PA, USA
}

Accepted 8 January 2021

Pre-press 2 February 2021

\begin{abstract}
.
Background: Religious and spiritual interventions may have an effect on Alzheimer's disease prevention. Kirtan Kriya meditation has been shown to mitigate the deleterious effects of chronic stress on cognition, reverse memory loss, and create psychological and spiritual wellbeing, which may reduce multiple drivers of Alzheimer's disease risk.

Objective: To detail a new concept in medicine called Spiritual Fitness, a merging of stress reduction, basic wellbeing, and psycho/spiritual wellbeing to prevent Alzheimer's disease.

Methods: The literature on the topics mentioned above is described, including an in-depth discussion on why and how each are critical to advancing the future of Alzheimer's disease prevention. The many negative effects of chronic stress, and the benefits of Kirtan Kriya, are reviewed. The four pillars of basic wellbeing, six practical aspects of psychological wellbeing, and the four new non-sectarian features of spiritual fitness are then disclosed. Moreover, instructions on practicing Kirtan Kriya are offered in the Supplementary Material.

Conclusion: Religious and spiritual practices, including Kirtan Kriya, are crucial components in the development of enhanced cognition and well-being, which may help prevent and, in some cases, reverse cognitive decline. The key point of this review is that making a commitment to live a brain longevity lifestyle including spiritual fitness is a critically important way for aging Alzheimer's disease free. We hope that this article will inspire scientists, clinicians, and patients to embrace this new concept of spiritual fitness and make it a part of every multidomain program for the prevention of cognitive disability.
\end{abstract}

Keywords: Alzheimer's disease prevention, Kirtan Kriya meditation, neurotheology, peace of mind, psychological well-being, purpose in life, spiritual fitness, spiritual well-being, spiritual/religious involvement, unlimited love

\section{INTRODUCTION}

The ultimate purpose of this article is to review how religious and spiritual involvement may prevent Alzheimer's disease (AD). Additionally, it presents research not only on the various aspects of religious and spiritual involvement but also on a practical approach to achieving spiritual fitness ${ }^{\mathrm{TM}}$, a new concept

\footnotetext{
*Correspondence to: Dharma Singh Khalsa, MD, President/ Medical Director, Alzheimer's Research and Prevention Foundation, PO Box 30783, Tucson, AZ 85751-0883, USA. Tel.: +1 888 988 5766; E-mail: drdharma@alzheimersprevention.org.
}

combining multiple aspects of religious involvement, spirituality, and psychological well-being [1,2].

An important component of that practical approach is the regular practice of techniques enhancing spiritual fitness. Kirtan Kriya will be introduced later as an example of a memory meditation exercise suitable for everyday use with numerous effects on spiritual fitness hallmarks suggested in multiple research studies.

In a systematic review of the effect of religious and spiritual involvement on cognitive function from $2019,82 \%$ of the research articles reported positive 
associations between religious involvement, spirituality, and brain health. According to the above-noted systematic review, religious and spiritual involvement appears therefore to be protective against cognitive decline in middle and old age adults [3, 4]. The opposite appears to be true as well. According to research by Dos Santos, lower spiritual well-being is associated with mild cognitive impairment (MCI) and early dementia [5].

With the aging of the world's population, AD continues to be a serious problem including increased caregiver stress and burden. Currently there are 5.7 million cases in the United States (US), about 44-50 million cases worldwide and approximately 150,000 deaths each year in America, making AD the third leading cause of death in the US among seniors before the COVID-19 pandemic [6]. Of note is that African Americans and other underserved populations are twice as likely to suffer from AD [7]. Dire predictions are for total case numbers to surge to 14-16 million Americans living with $\mathrm{AD}$ and up to 152 million worldwide by 2050 [8]. If a preventative approach does not gain widespread utilization, financial costs are estimated to further soar in the future. In the US alone, $\mathrm{AD}$ and all forms of dementia cost the nation an estimated $\$ 305$ billion in 2020 [9].

There are no drugs that have a substantial positive impact on either the prevention or reversal of cognitive decline [10]. Living a particular type of lifestyle is the only proven way to possibly slow or prevent the onset of $\mathrm{AD}[11,12]$. In an ongoing study of lifestyle modification, The Finnish Geriatric Intervention Study To Prevent Cognitive Impairment and Disability (The FINGER Study), the effects of an intervention targeting several lifestyle and vascular risk factors were studied simultaneously. It indicated that utilizing nutritional intervention, physical exercise, cognitive training, and social activities together results in a significant beneficial effect on overall cognitive performance [13-15].

As mentioned at the outset and according to the MacArthur Foundation Research Network on Successful Aging, spirituality and religious participation are highly correlated with positive successful aging, including the maintenance of good cognitive function throughout life. In fact, spirituality and religious participation may be just as beneficial as diet, exercise, mental stimulation, and social connectedness $[16,17]$. Conversely, compared to those who report the same level of continuous religious involvement, subjects who report less religious observance now than 20 years ago commonly show more cognitive difficulties [18]. Moreover, spirituality, as we will soon see, moderates positive relationships with various measures of life satisfaction, psychosocial wellbeing, both physical and mental health, and is helpful in the quest for meaning and purpose in life [19].

Not unlike physical fitness, which has a clear benefit in improving cognitive function, both independently and as part of an integrative medical program [20], spiritual fitness, especially as developed through meditation exercises such as Kirtan Kriya $(\mathrm{KK})$, discussed in this paper, is effective in improving cognition $[21,22]$. Once clinicians, psychologists, social workers, and others become aware of this new advance, the concept of spiritual fitness may be easily incorporated into an $\mathrm{AD}$ prevention program.

\section{RELIGION, SPIRITUALITY, HEALTH, AND WELL-BEING}

It is a major premise of this article that today's detrimental stressful existence impedes the creation of a healthy lifestyle, including psychological and spiritual well-being, while well-being augments brain function and may prevent AD [23]. Most people intuitively know what religion is: the practice of a certain set of rules, rituals, and traditions that bring one closer to God. However, what is spirituality itself?

In 2008, Koenig argued that spirituality should be sharply defined, especially from a research perspective [24]. In his 2020 Handbook of Spirituality, Religion, and Mental Health, he states, however, that people in Western nations are going through a transition to less religious identity over all [25]. For example, he cites that $89 \%$ of Americans believe in God, $90 \%$ pray on a regular basis, yet only $77 \%$ report affiliation with a religious group [18]. However, 82\% acknowledge the need for spiritual growth [26]. Also of note is that $84 \%$ of the world's population is religiously affiliated, and $68 \%$ of unaffiliated individuals believe in a higher power [27]. Additionally, according to a Yoga Alliance/Yoga International study published in 2016, at least 36 million Americans practice yoga and 300 million do so worldwide, while 80 million Americans are likely to try yoga within 12 months [28]. The number of people who meditate in the US is now at least 35 million [29].

Since Koenig's 2008 thesis, spirituality, both in the academic context and in the non-academic sense, has taken on an important new texture. Many people may think of themselves as "spiritual" but not necessarily religious, while similarly, some consider 
themselves both religious and spiritual. The number of people who consider themselves religious but not spiritual is not reported but is generally considered low [19]. Purely speaking, the notion of spirituality has grown to where it is considered an inner-directed construct that involves an individual's, "search for the sacred or higher power" both within themselves and perhaps outside as well, such as in nature [30]. Spirituality activates a particular spark within an individual that encompasses connection-religious or otherwise-with a non-physical reality as perceived by the person. Spirituality, therefore, is a broad term referring to any activity that brings a divine or metaphysical quality to the individual, and religion, by contrast, is a specific term referring to such aspects of life that are shared with others within a named institutional/cultural group [18].

Religiosity is often measured using the five-item Duke University Religion Index [31]. There are also a number of analysis and research studies, which define the most useful quantitative domain measures of spirituality such as the SHALOM or The Spiritual Well-Being Questionnaire, the Fisher Scale and others. SHALOM is a multidimensional scale of spirituality based on the synergy between theism, environment, community, and personal development. The theme running through this research, as alluded to above, is connection: with self, others, and/or God. However, recent studies have shown that relating to God in one's own way, is most important for spiritual well-being. Beyond that, however, no one scale has proven to be more accurate than any other [32-34].

Today, spiritual well-being generally refers to a subjective experience of the deepest values and meanings by which people live. This is often outside the context of an organized religion although many religious people use the characteristics of their faith to bring themselves to these heightened experiences and values that guide their life [35].

Herein, although spirituality is not defined rigidly, it is characterized by a group of developmental, behavioral, and experiential characteristics that one experiences along a path of personal growth, which eventually leads to spiritual fitness. Today, therefore, spirituality, personal growth, or transformation, is considered separately from organized religious institutions. This idea of spirituality may be part of every religion or separate from it. Significantly, having a sense of spiritual connection and optimal personal development, what Jung called individuation, regardless of its origin, reduces risk and slows $\mathrm{AD}$ progression [36, 37].

\section{STRESS, COGNITION, AND WELL-BEING}

As evidenced by the recent Lancet review paper on dementia prevention, where stress and stress management go unmentioned, it is still an underappreciated and under discussed topic [38]. Beyond the physical, stress can also be psychological or emotional, and the potency and pathogenicity of psychological stress cannot be ignored, as it may increase the risk of developing AD [39-41]. In contrast, spiritual practices including KK, may counterbalance many aspects of the stress response and protect the brain specifically from the ravages of aging combined with stress overload [42-44]. It is not an understatement to say that the US, and indeed the world, is in a state of unbridled perpetual stress and turmoil. With that is seen a surge in anxiety, depression, post-traumatic stress disorder, and other stress-related illnesses, such as cardiovascular disease including hypertension, diabetes, neuroinflammation, a lack of exercise, poor sleep, and an unhealthy diet, all risk factors for the development of $\mathrm{AD}$ [45]. With the advent of lockdowns due to COVID-19, although technological communication such as Zoom, FaceTime, and the like have been utilized extensively, it has been established that social isolation and loneliness are rampant [46]. This lack of connection and community, moreover, is shown to increase depression symptoms during the COVID-19 pandemic, elevating AD risk [47, 48]. Beyond that, it is now clear that many survivors of COVID-19 are left with an indelible imprint of neuroinflammation as well as multiple organ negative parameters in physiological function, including a penchant for cardiovascular, pulmonary, neurologic disease, and cognitive decline, all risk factors for $\mathrm{AD}$ as well $[49,50]$. Moreover, as suggested by Koenig, spirituality helps COVID-19 survivors nor only cope with their pathology but enhance their cognition and prevent decline [51, 52].

Additionally, high levels of stress toxicity involved in adverse childhood experiences and early life stress such as trauma, abuse, or neglect are risk factors for cognitive decline [53]. Early stressors, such as abuse, can result in a multiplicity of negative biomarkers and unhealthy behaviors, which suggest a dose-response relationship between severity of early adversity, and inflammation, shorter telomeres, and other unhealthy biological markers $[54,55]$. The effects of early life stress may be more important in advanced age than self- reports of early life adversity and stress. This highlights the importance of the use of regular meditation techniques such as $\mathrm{KK}$, and spirituality, as 
positive habits to develop during the aging process. Moreover, it is possible that older adults underestimate their level of life stress and early adversity [56]. According to research by Jiang et al, the underlying cause of the cognitive decline produced by adverse childhood experiences is an epigenetic phenomenon leading to a perturbation in DNA methylation and histone modification resulting from prenatal maternal stress and a lack of nurturing during infancy [57, 58]. Such epigenetic modifications not only affect the individual's stress response, but also the stress response of future generations [18].

Gene-environment interactions involving the $A P O E \varepsilon 4$ allele may also play a role in AD risk from stress. In fact, research has already shown that spirituality can modify the effect of the APOE4 gene on MCI in adults 55 and older by increasing telomere length [59]. In other words, spirituality and meditation practices such as KK and other techniques may influence cellular aging, through modifying the effect that high-risk genes have on increasing vulnerability to cognitive impairment and AD [60-62].

Chronic stress, via its well- known cortisol connection, its hippocampal and limbic system toxicity, and epigenetic damage, is a causative factor in the development of cognitive decline and decreased wellbeing $[63,64]$. Coming full circle, this diminishment of well-being may lead to a loss of cognitive function, while an improvement in well-being actually augments cognition and prevents cognitive decline [65]. In addition, the negative lifestyle habits that decrease cognition and well-being are less prevalent in individuals who are either religious or spiritual [18]. Compelling research thus suggests that stress has a pronounced negative effect on cognition, including injuring genes by decreasing the level of the enzyme telomerase. While shorter telomeres are associated with poor immune system function, inflammation, accelerated aging, and $\mathrm{AD}$, longer telomeres may equal a longer life with a clear mind. Indeed, the

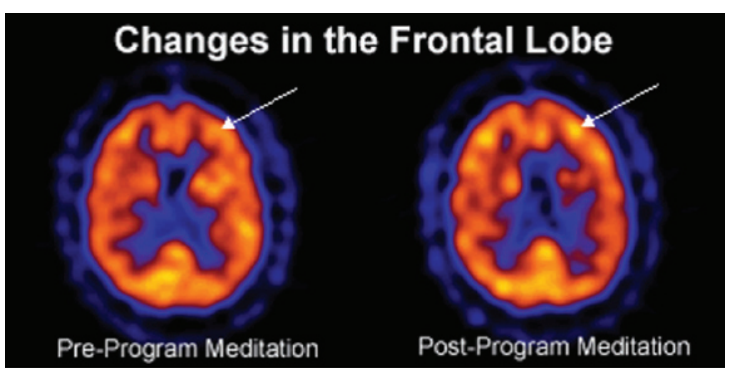

Fig. 1. Changes in the frontal lobe. effects of various spiritual practices on telomerase activity, telomere length, and immune cell aging is well documented [61]. Herein, we introduce KK, which has multiple documented effects on stress, while increasing telomerase and telomere length, slows cognitive decline, and acts as a bridge between chronic stress and the development of spiritual fitness [66-69].

\section{KIRTAN KRIYA: THE BRIDGE BETWEEN STRESS AND SPIRITUAL FITNESS}

While KK is shown to specifically reverse memory loss [70] and takes only 12 minutes once a day, other meditation techniques which are more time consuming $[22,23]$ suggest inconsistent effects on cognition and perhaps only a trend toward improvement. They have not been shown to impact significantly memory loss, however.

Beyond cognitive improvement, research on KK for the past two decades suggests it has multiple positive benefits on anxiety and depression while improving sleep hygiene. KK increases blood flow to multiple brain anatomical areas that are involved in cognition and emotional regulation, including the hippocampus, anterior and posterior cingulate gyrus, frontal lobes, and pre-frontal cortex [71]. This is highly significant in view of a study by Pa that suggests that decreased blood flow may be meaningfully associated with tau build-up in the brain [72]. Moreover, a recent report by MacDonald suggests that during normal aging cerebral blood flow reduction and cerebral cortical thinning are typically observed. KK increases gray matter volume and decrease ventricular size in long- term practitioners, which may therefore slow brain aging [70, 73, 74].

As can be seen in the scans below in Figs. 1 and 2, KK practice activates the prefrontal cortex, the frontal lobe, and the anterior cingulate gyrus, both the first time the subjects practiced it and, more prominently, after eight weeks of practice [70].

The activation of the prefrontal cortex is especially important because diminished prefrontal cortex activity is associated with MCI [70]. The prefrontal cortex sends reciprocal fibers to the limbic system including the amygdala to stabilize emotions. The anterior cingulate cortex improves stress regulation and, of specific interest, is the finding that the well-known Super Ager Study revealed that the oldest old who maintained optimal memory function had a larger anterior cingulate gyrus and cerebral cortex; these 


\section{Changes in the Anterior Cingulate Gyrus}
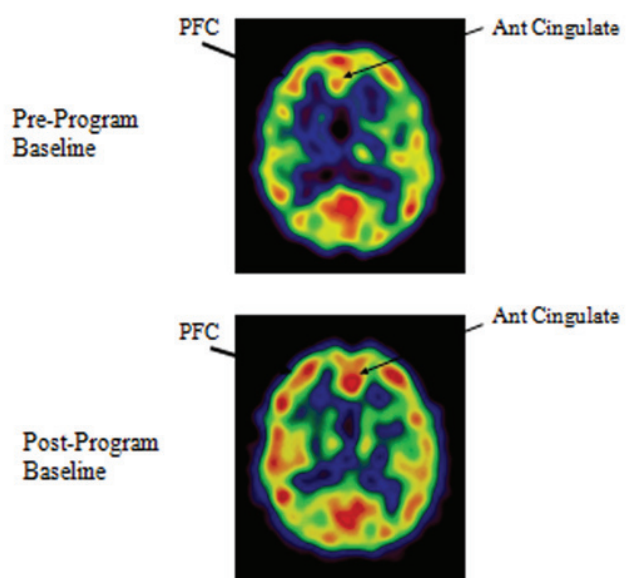

Fig. 2. Enhanced cerebral blood flow in the prefrontal cortex and anterior cingulate gyrus.

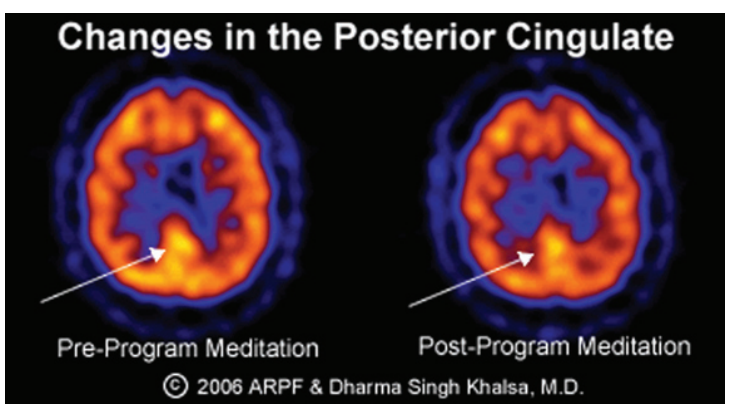

Fig. 3. Changes in the posterior cingulate gyrus.

same two findings seen in people who practiced KK [70, 74-76]. Separately, super-aging appears to be associated with the resistance to tau and amyloid- $\beta$ pathology, which likely permits maintenance of cognitive performance despite advancing age. In turn, differences between normal aging and MCI appear to be driven in large measure by amyloid- $\beta$ burden [77]. Of note is that KK may decrease brain amyloid- $\beta$ burden as evidenced by increased plasma amyloid- $\beta$ [61].

The activation of the posterior cingulate gyrus is most relevant because it is highly connected to other important anatomical areas and one of the most metabolically active regions in the brain [71]. It is hence critically important for many types of memory and emotional functions. Reduced cerebral blood flow and hypometabolism in the posterior cingulate gyrus are early signs of AD and are frequently present before a clinical diagnosis is evident, indicating a particular vulnerability of this structure to neurode- generation. Furthermore, in early $\mathrm{AD}$, the connection between the posterior cinguate gyrus and the hippocampus is disrupted [78].

KK may work by several neurochemical mechanisms including stabilizing the brain synapse by increasing important neurotransmitters, such as acetylcholine, norepinephrine, and gamma aminobutyric acid [79-82]. This is significant, as previous research suggests that synaptic dysfunction is also a unique hallmark of AD [83-85]. Moreover, two aspects utilized in KK, singing and touching the fingertips in sequence, stimulate the cortical homunculus, a representation of anatomical divisions of the motor-sensory cortex, the tongue, vocal apparatus and the dense nerve endings in the fingertips [86]. Such enhancement of the brain with increased blood flow has beneficial effects and may provide optimal protection against neurodegeneration [70].

Additionally, in a study of 37 stressed family dementia caregivers, the KK group had significantly lower levels of depressive symptoms, and greater improvement of mental health, well-being, and memory, compared with the relaxation control group. The KK group showed a $43 \%$ improvement in telomerase activity, the largest ever reported, compared with $3.7 \%$ in the control. These findings suggest an improvement in stress-induced cellular aging. A further study found positive epigenetic effects with an up regulation of 19 genes related to positive immune function and a down regulation of 49 genes associated with inflammation, such as pro-inflammatory cytokines, potentially indicating lower AD risk [87].

Most recently, a study utilizing both kundalini yoga and KK together in subjects with MCI suggested a marked improvement in memory compared to the gold standard, Memory Enhancement Training. This research also suggested that the kundalini yoga and KK group showed short- and long-term improvements in executive functioning as compared to Memory Enhancement Training, and broader effects on depressed mood and resilience [88, 89]. Further, published studies in subjects with subjective cognitive decline (SCD) suggest that KK compared to a music listening control improved memory, mood, and general brain function. Those subjects who practiced KK most consistently had the best results and enjoyed the greatest increase in telomerase and telomere length and plasma concentration of amyloid- $\beta$ [61]. Additional biomarker results were associated with improvements in cognitive function, sleep, mood, and well-being, suggesting a potential functional relationship [90, 91]. 
KK can be performed by people of any age without memory loss or with various degrees of impairment. Moreover, the benefits accrue from the very first practice session and requires no other training sessions, seminars, retreats, additional practices, or costs [60, 70]. This is critically important as utilizing online sources obviates the need for in person training, especially if the COVID-19 pandemic is still an issue. KK therefore is a multifaceted, multisensory exercise that in normal individuals, caregivers, and those with cognitive decline improves cognition, slows memory loss, improves mood and with practice may embolden a person's spiritual growth in this age of anxiety $[67,70,84]$. The chart below summarizes the many potential benefits of KK, all of which boost brain function, improve sleep, and provide a vehicle to develop heightened levels of well-being and spiritual fitness.

To discover how to do KK, please see the Supplementary Material.

\section{SPIRITUAL FITNESS: THE NEW DIMENSION IN ALZHEIMER'S DISEASE PREVENTION}

We have discussed extensively the effects of chronic unrelenting stress on cognitive health and wellbeing. We have suggested that not only do people who practice spiritual techniques such as KK lower their risk for dementia, they may enter a new dimension called spiritual fitness, an interweaving of basic, psychological, and spiritual well-being [92]. Since the components of spiritual fitness as defined below are used to help moderate life stressors and soften their effects on mental and physical health, spiritual fitness may reduce their effects on cognitive functioning through this clear pathway [93]. Spiritual fitness may affect $\mathrm{AD}$ risk by reducing depressive symptoms, engendering positive emotions, and influencing affirmative personality traits such as conscientiousness, optimism, and agreeableness, as well as the other attributes of spiritual fitness, including the development of inner peace $[18,94]$. Spiritual fitness also includes greater social support, larger social networks, and less loneliness, critically important during the COVID-19 pandemic, which has lowered emotional well-being by as much as $74 \%$ [95]. It is also associated with a greater likelihood of marital and family stability. These influences may also result in a lower risk for $\mathrm{AD}[18,26]$.

In a 3-year study presented at The Alzheimer's Association International Conference in 2018, spirituality, fostered especially by meditation, was associated with lowered atrophy rates in brain regions related to memory, visuospatial attention, and behavioral deficits in subjects at risk for AD [96].

Medically, spiritual fitness may reduce the risk of coronary artery disease, hypertension, stroke, and diabetes, medical conditions that also predict strongly the development of AD in later life [97]. Finally, the development of spiritual fitness has great positive impact on health behaviors such as diet, exercise, meditation, and prayer as well as lessening negative behaviors such as cigarette smoking, excessive alcohol consumption, and illicit drug use [18, 26]. Physiologically, religious and spiritual involvement increase levels of brain derived neurotrophic factor (BDNF), as revealed by Mosqueiro and colleagues. BDNF is a key component in the brain responsible

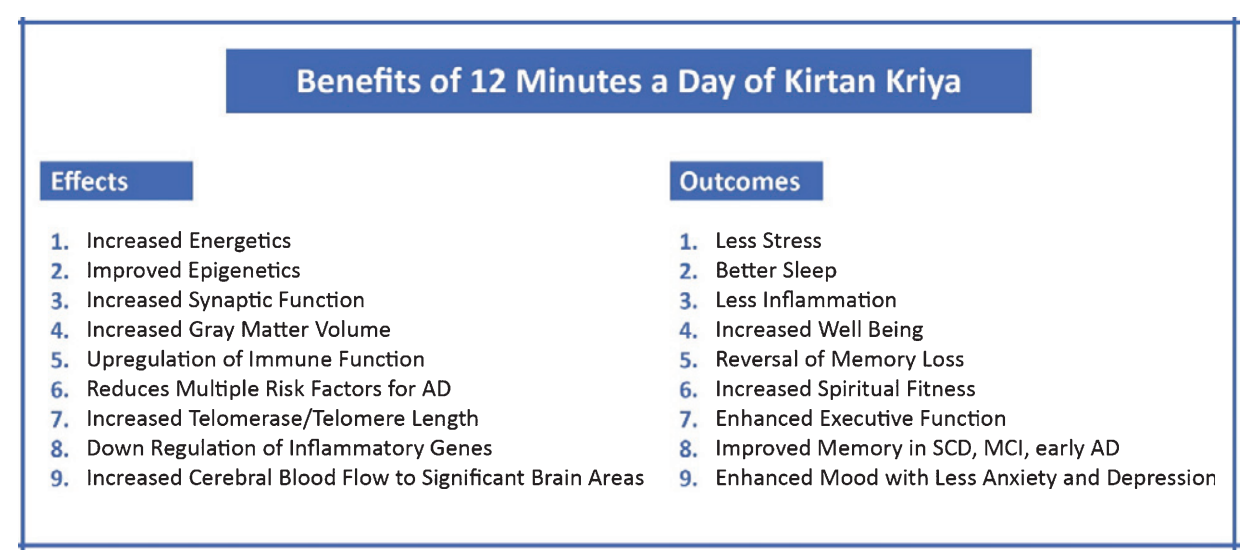

Fig. 4. Benefits of Kirtan Kriya. 
for synaptic plasticity, dendritic and neuronal fiber growth, and neuronal survival [98]. Most significantly, religious and/or spiritual activity is associated with better cognitive function in old age [99-101]. Thus, there are multiple medical, psychological, and behavioral mechanisms by which spiritual fitness might impact AD risk.

\section{BASIC WELL-BEING}

In their seminal book called Well-being, Rath and Harter discuss what they describe as "the five essential elements" [102]. Their work was based on a comprehensive Gallup study of people in more than 150 countries, which revealed 5 universal interconnected elements that shape people's lives:

1. Career well-being: How you occupy your time or simply liking what you do every day.

2. Social well-being: Having strong relationships and having love in your life.

3. Financial well-being: Effectively managing your financial life.

4. Physical well-being: Enjoying good health and having enough energy to get things done on a daily basis.

5. Community well-being: Having a sense of engagement in the area where you live.

The authors contend that these five elements are what make life worthwhile. Their research reveals that while $66 \%$ of people are doing well in at least one of these areas, just $7 \%$ are thriving in all five. A lack of well-being is a risk factor for AD or perhaps more accurately stated: when a person enjoys well-being, especially psychological and spiritual well-being, they are lowering their risk factors for the development AD. As the authors point out: "Although these basic elements of well-being are universal across faiths, cultures, and nationalities, people take different paths to increasing their individual well-being. What is common to many of them, however, is that spirituality, but not necessarily religion, drives them in all these areas. For others, however, it is their faith that may be the most important facet of their lives. And yet for others, a sense of purpose or a deep mission, such as protecting the environment, inspires them each day" [102]. Having a purpose in life is critically important to AD prevention, especially because it not only reverses multiple drivers of risk for $\mathrm{AD}$, and as described below, is an independent variable for AD prevention by itself [103].

\section{PSYCHOLOGICAL WELL BEING INCLUDES THE FOLLOWING: [104-106]}

1. Acceptance: You are able to accept life as it is and people as they are and make the best of it. You change what you can and perhaps drop what you cannot.

2. Self-esteem or self-efficacy: The deep knowledge that what you do makes a difference in your health and well-being.

3. Independence: You live free from the influence of others' negative thoughts towards you. You are your own person, comfortable in your own skin. You also look forward to living independently in your own home for as long as possible.

4. Persistent personal growth: The desire and ability and continued practice of health-promoting behaviors such as a good diet including perhaps supplementation, stress management, including scientifically proven yoga and meditation techniques, and regular physical and mental exercise, which promotes personal growth and well-being. Personal growth is also about the continual realization of one's talents and potential. High scores on the personal growth evaluation scale indicates that one continues to develop and recognize improvement in behavior over time. In studies an example for this criterion is, "I think it is important to have new experiences that challenge how I think about myself and the world" [107].

5. Positive relationships with others: Called a sangat in the East, or a congregation, it is essentially being with like-minded people with whom you share love and support. Maintaining good family ties along with a strong community is integral to positive relationships. High scores reflect engagement in meaningful association with others that include reciprocal respect. Positive relations with others involve close connections, intimacy, and unconditional love [23].

6. Purpose in life (PIL): Discovering purpose life is shown independently to reduce AD risk [103]. It also lowers the risk of myocardial infarction, stroke, and disability [108, 109].

\section{THE HEART AND SOUL OF PURPOSE}

As suggested above, psychological well-being (PWB) may reduce inflammation, cholesterol; reduce risk of myocardial infarction, stroke, and the inci- 
dence of disability [110-113]. It is also linked with decreased use of preventive care services and mortality among community-dwelling older persons [114, 115]. Most significantly, as revealed in more detail shortly, PIL lowers the risk for AD [23, 116]. Findings in aging women show that those enjoying PWB had lower levels of salivary cortisol, pro-inflammatory cytokines, and cardiovascular risk, and longer duration REM sleep compared with those showing lower levels of PWB [92]. Ill-being, conversely, increases levels of cortisol, epinephrine, norepinephrine, and IL-6 $[92,117]$. Higher levels of PWB, including purpose, may also increase telomere length and reverse the deposits of amyloid- $\beta$ plaques in the brain, limiting the effects of the disease [118, 119]. Moreover, PWB increases life expectancy by about eight years [120, 121]. Regarding PIL specifically, in a landmark 7 -year project by Boyle, 900 community dwelling older persons without dementia were studied and the effect of PIL on risk for AD and MCI was examined. PIL was assessed using a 10-item scale derived from Ryff's longer scale of Psychological Well-Being [115].

The results suggest that a person with a higher score on the PIL measure was 2.4 times more likely to remain free of $\mathrm{AD}$ than one with a low score, which persisted beyond all controls for depressive symptoms, level of distress, social network size, and number of chronic medical conditions. Therefore, the conclusion of this work is that greater PIL is associated with a reduced risk of AD and MCI [103]. Another study suggests that PIL modified the association between pathologic changes in $\mathrm{AD}$ and cognition such that participants who reported higher levels of PIL not only exhibited better cognitive function, but in conjunction with that, PIL protected those with already existing pathological changes, thus slowing their decline. Boyle postulates that having a purpose stimulates the brain of the individual as well as having anti-anxiety and anti-depressant effects [118].

Regardless of what an individual believes about their purpose, finding one has significant positive health outcomes during aging and compression of morbidity including fewer chronic conditions, less disability, and reduced mortality. Indeed, in a paper published in the journal Population Health Management in 2018, Musich and Wang address a multivariate regression model to determine characteristics of PIL levels and the impact of health care utilization and expenditures, preventive services compliance and quality of life [109]. The study suggested that PIL is strongly associated with improved mental and physi- cal health outcomes among older adults. The authors conclude by stating, "Interventions to improve and or maintain higher levels of PIL, over time may promote successful aging," which includes cognitive health. The negative impact of stress on health was also buffered by PIL. Toward the end of life, many people look back and realize that their main purpose was to develop a relationship with the divine aspect of themselves and reconnect with who they really are: their spirit. They often ask, "Did I love enough and was I loved? Did I live a life in tune with my best and highest spiritual self?" [122]. Various meditation practices including KK help to develop PWB and create spiritual fitness, which we now know may not only prevent AD but also slows its progression [18, 36, 118, 123, 124].

\section{SPIRITUAL FITNESS AND AD PREVENTION}

Burgeoning inquiry now suggests that the healthiest people are the ones who grow with age and experience; even in times of trouble like these. It is also well known, as discussed above, that PWB leads to the type of energy and resilience that help us create a buffer against illness, inflammation, anxiety, depression, and cognitive decline $[125,126]$. The new concept of spiritual fitness interweaves PWB with four non-sectarian features that may enable a person to achieve high levels of cognitive health [23].

1. Patience: Not unlike the persistent personal growth of PWB, patience leads to maintaining regular healthy habits such as proper diet, exercise, and stress management. Patience also conveys personal empowerment and growth. Personal growth is about continual realization of your talents and higher potential. This brings unlimited happiness and abundance. Developing patience also allows you to slow down and enjoy life. Patience includes looking forward and seeing what possibilities are there in the future and being able to wait calmly for them to arrive.

2. Awareness: Awareness brings self-acknowledgement and self-appreciation. Self-awareness is how an individual consciously knows and understands their own character, feelings, motives, and desires. Naturally, when you see your true self without judgment, you can view others in the same way and look beyond their faults. This leads to gratitude and forgiveness, which release anger, a devastating toxin to your brain, immu- 
nity, and genes. Anger has been associated with $\mathrm{AD}$ risk factors including elevated glycosylated hemoglobin, elevated waist- hip ratio, increases of visceral adipose tissue, and lower levels of HDL cholesterol [127-129]. As you gain the knowledge of who you are on a deep level, you can break through unconscious thought patterns that shroud your true identity and correct them as needed. This allows you to clarify your PIL [130]. Another type of awareness is situational awareness. That is when you are alert to your surroundings and how they influence your stress and well-being, including your connection to your higher power. Self-awareness is involved with working memory, processing speed, and reasoning, all important functions to maintain as they decline as memory loss ensues and progresses. There are particular brain circuits involved in self-awareness [131].

3. Compassion: Compassion or living with love is a strength and conveys kindness and empathy, which embolden healthier communication. The term itself contains a large number of meanings because it appeals to different emotions such as generosity, altruism, solidarity, hospitality, accompaniment and solace among others. Indeed, as suggested by Perez-Bret, compassion originates as an emphatic response to suffering, which nurtures well-being, through specific ethical actions directed to finding a solution to that suffering $[132,133]$. This applies to the general population but especially to those in the field of health care for as Torralba points out, compassion consists of perceiving the suffering of others as belonging to us and experiencing it as our own [134]. As described by Nouwen, compassion may also signify full immersion in the condition of being human [135]. Compassion also fosters clarity, commitment, and the courage to be yourself without fear. You can then pass to the next level of spiritual fitness, which is surrender. Compassion is an excellent heart and immune system healer [136].

4. Surrender: The stretch of surrender is to your spirit, your soul. It also involves faith and trust in your higher power. During these uncertain times, many people are searching for the infinite within themselves [51, 52, 96]. When you surrender to your soul, you gain the strength to sacrifice and to serve or give to others without thought of reward for yourself. This altruism brings with it a deep and lasting happiness and serenity, which conveys peace of mind, a much-needed brain health and immune system balm [137, 138]. Faith helps people handle difficult life situations such as the death of a loved one, illness, addiction, or natural disaster [139].

Progressing on one's spiritual path evokes an experience of what Post calls "unlimited love", which he considers the "ultimate reality" [130]. Not unlike compassion, this ultimate reality encompasses altruism. In this heightened state of evolution, one has the ability to hear their inner voice and beyond that, truly see the other as him or herself. Spiritual fitness is also a way to develop personalized, patient-centered healthcare that may include or transcend religion and accents the process of self-discovery [92]. KK and spiritual fitness are associated with distinct positive psychological outcomes, many of which can affect cognition, and are more relevant, according to work by Montero-Marin, than even religious beliefs [140].

Although $\mathrm{KK}$ is a fast and reliable way to clarify PIL and develop spiritual fitness, other mind/body practices, attending religious services, prayer, bible reading, being in nature, altruism, sharing our own happiness, and grace may also lead to a higher level of spiritual fitness.

\section{SPIRITUAL FITNESS AND NEUROTHEOLOGY}

The overall relationship between spiritual fitness and a person's complete physical and mental health is a topic of investigation in the emerging field of study called neurotheology. Neurotheology explores the relationship between the brain and our spiritual or religious self [141, 142]. Neurotheology may also be called Spiritual Neuroscience [79]. Early work has focused on both the theoretical development of models regarding which brain areas are affected through spiritual practices such as meditation or prayer. Moreover, in the past 20 years, there has been an extensive growth in neuroimaging and other physiological studies evaluating the effect of meditation, spiritual practices, and mystical experiences $[143,144]$. The result is that a number of brain structures are typically involved with meditation practices, and concomitantly, we would expect them to be involved in spiritual fitness [145].

For example, we have observed decreased frontal lobe function associated with feelings of surrender and changes of activity in the parietal lobe and related social brain areas involved with feelings of compassion [146, 147]. Further, in our original neuroimaging study of KK, we found long-term brain effects, not 
just during meditation, but afterwards [70]. Thus, neurotheological studies can help understand how a practice such as KK can lead to more permanent effects in brain function that support spiritual fitness. Similarly, neurotheological studies of spiritual practices can provide a foundation for understanding more practical applications. By observing brain changes involved in meditation practices, we can determine the underlying mechanism by which it improves memory and concentration.

For future scientific research, it would be helpful to categorize meditation types depending on the neural networks, brain chemistry, anatomical and EEG changes involved. For example, although KK involves multiple aspects such as breath, finger-tip movements, and singing, i.e., mantra, it belongs to the focused attention meditation practices similar to transcendental meditation or Yogic meditations, while mindfulness or Vipassana meditation belong to the open awareness practices [148]. Each of these types of meditation rely on different neuronal networks, brain anatomical changes, biochemistry, and brain wave changes. Hence this can explain different results concerning the effect on cognitive processes and might be suitable for different health conditions, thus making KK and other practices useful as a precise meditation as medicine prescription. Such knowledge could be useful for directing future research exploring other aspects of both physical and mental health.

\section{A NEW BEGINNING}

Mitigating the extensive negative biochemical effects of stress with meditation practices, in tandem with the creation of heightened levels of spiritual fitness, may help lower the risk for AD. This review paper highlights the research done on KK, successfully employed in studies of people with SCD and $\mathrm{MCI}$, as well as highly stressed caregivers. Research suggests that KK reduces AD risk by improving sleep, decreasing depression, increasing well-being, downregulating inflammatory genes, upregulating immune system genes, maximizing insulin and glucose metabolism, improving sleep, and increasing telomerase, as well as increasing actual telomere length. Moreover, multiple studies have all illumined objective evidence of memory loss reversal when studying KK [21, 60, 87, 89]. KK also impacts a number of aspects of mental health leading to spiritual fitness, important for maintenance of cognitive function.
Small shifts in one's daily routine can make all the difference in $\mathrm{AD}$ prevention. If physicians, patients, scientists, and others made such changes with their patients, colleagues, and friends, we would know that everything possible is being done to slow the $\mathrm{AD}$ epidemic now and into the future [151, 152, 154]. It is our hope that those who study the prevention and treatment of AD embrace this new concept of spiritual fitness and that soon so much progress is made that its use as part of a multidomain program will be considered mainstream.

We are optimistic that this article will inspire future research on the topic of spiritual fitness, which may bring more useful information in the field of AD prevention and modification of the clinical course of the disease.

It was Ralph Waldo Emerson who wrote, "What lies behind us and what lies before us are tiny matter compared to what lies within." This heightened level of consciousness and cognition is an important frontier in $\mathrm{AD}$ prevention, and a dimension that should be pursued further.

\section{ACKNOWLEDGMENTS}

We thank Kirti Khalsa, CEO of the Alzheimer's Research and Prevention Foundation (ARPF), for her preparation of the manuscript, and YB and GRD for inspiration.

The research on Kirtan Kriya was funded in part by ARPF.

Authors' disclosures available online (https:// www.j-alz.com/manuscript-disclosures/20-1433r1).

\section{SUPPLEMENTARY MATERIAL}

The supplementary material is available in the electronic version of this article: https://dx.doi.org/ 10.3233/JAD-201433.

\section{REFERENCES}

[1] Rosemarin DH, Koenig HG (2020) Handbook of Spirituality, Religion, and Mental Health, second edition. Academic Press/Elsevier, Oxford.

[2] Rosemarin DH (2018) Spirituality, religion, and cognitivebehavioral Therapy: A guide for clinicians. Guilford Publications, New York.

[3] Hosseini S, Chaurasia A, Cooke M, Oremus M (2016) Effect of religious involvement on cognition from a lifecourse perspective: Protocol for a systematic review and meta-analysis. BMJ Open 6, e011301. 
[4] Hosseini S, Chaurasia A, Oremus M (2019) The effect of religion and spirituality on cognitive function: A systematic review. Gerontologist 59, e76-e85.

[5] Dos Santos SB, Rocha GP, Fernandez LL, de Padua AC, Reppold CT (2018) Association of lower spiritual wellbeing, optimism and hope scores with mild cognitive impairment and mild dementia. Front Psychol 9, 371.

[6] (2020) Alzheimer's Facts and Figures, a special report of the Alzheimer's Association.

[7] Babulal GM, Quiroz YT, Albensi BC, Arenaza-Urquijo E, Astell AJ, Babiloni C, Bahar-Fuchs A, Bell J, Bowmanmn GL, Brickman AM, Chételat G, Ciro C, Cohen AD, Dilworth-Andersons P, Dodge HH, Dreux S, Edland S, Esbensen A, Evered L, Ewers M, Fargo KN, Fortea J, Gonzalez H, Gustafson DR, Head E, Hendrix JA, Hofer SM, Johnson LA, Jutten R, Kilborn K, Lanctôt KL, Manly JJ, Martins RN, Mielke MM, Morris MC, Murray ME, Oh ES, Parra MA, Rissman RA, Roe CM, Santos OA, Scarmeas N, Schneider LS, Schupf N, Sikkes S, Snyder HM, Sohrabi HR, Stern Y, Strydom A, Tang Y, Muniz Terrera G, Teunissen C, Melo van Lent D, Weinborn M, Wesselman L, Wilcock DM, Zetterberg H, O'Bryant SE (2019) Perspectives on ethnic and racial disparities in Alzheimer's disease and related dementias: Update and areas of immediate need. Alzheimers Dement 2, 292-312.

[8] Prince M, Bryce R, Albanese E, Wimo A, Ribeiro W, Ferri CP (2013) The global prevalence of dementia: A systematic review and meta analysis. Alzheimers Dement 9, 63-75.e2.

[9] Gaugler J, James B, Johnson T, Marin A, Weuve J (2019) Alzheimer's disease facts and figures. Alzheimers Dement 15, 321-87.

[10] Carrillo MC, Thies W, Bain L (2012) The global impact of Alzheimer's disease. In Alzheimer's DiseaseModernizing Concept, Biological Diagnosis and Therapy, Hampel H, Carillo MC, eds. Adv Biol Psychiatry, vol 28. Karger, Basel 28 pp. 1-14.

[11] Christensen K, Thinggaard M, Oksuzyan A, Steenstrup T, Andersen-Ranberg K, Jeune B, McGue M, Vaupel JW (2013) Physical and cognitive functioning of people older than 90 years: A comparison of 2 Danish cohorts born 10 years apart. Lancet 382, 1507-1513.

[12] Matthews FE, Arthur A, Barnes LE, Bond J, Jagger C, Robinson L, Brayne C (2013) A two-decade comparison of prevalence of dementia in individuals aged 65 years and older from three geographical areas of England: Results of the Cognitive Function and Ageing. Lancet 382, 14051412.

[13] Kivipelto M, Solomon A, Ahtiluoto S, Ngandu T, Lehtisalo J. Antikainen R (2013) The Finnish geriatric intervention study to prevent cognitive impairment and disability (FINGER): Study design and progress. Alzheimers Dement 9, 657-665.

[14] Imtiaz B, Tolppanen A, Kivipelto M, Soininen H (2014) Future directions in Alzheimer's disease from risk factors to prevention. Biochem Pharmacol 88, 661-670.

[15] Ngandu, T, Lehtisalo J, Solomon A, Kivipelto M (2015) A 2 year multidomain intervention of diet, exercise, cognitive training, and vascular risk monitoring versus control to prevent cognitive decline in at-risk elderly people (FINGER): A randomized controlled trial. Lancet 385, 2255-2263.

[16] Crowther M, Parker M, Achenbaum WA, Larimore, W, Koenig, H (2002) Rowe and Kahn's model of successful aging revisited: Positive spirituality - the forgotten factor. Innov Aging 42, 613-620.

[17] Moore RC, Eyler LT, Mausbach BT, Zlatar ZZ, Thompson WK, Peavy G, Fazeli PL, Jeste DV (2015) Complex interplay between health and successful aging: Role of perceived stress, resilience, and social support. Am J Geriatr Psychiatry 23, 622-32.

[18] Koenig HG, VanderWeele V, Peeter J (2021) Handbook of Religion and Health, $3^{\text {rd }}$ ed. Oxford University Press, New York.

[19] Moberg DO (2001) Aging and spirituality: Spiritual dimensions of aging theory, research, practice and policy. Hayworth, Binghampton.

[20] Larson EB, Wang L, Bowen JD, McCormick WC, Teri L, Crane P, Kukull W (2006) Exercise is associated with reduced risk for incident dementia among persons 65 years of age and older. Ann Intern Med 144, 73-81.

[21] Eyre HA, Siddarth P, Acevedo B, Van Dyk K, Paholpak P, Ercoli L, St. Cyr N, Yang H, Khalsa DS, Lavretsky H (2017) A randomized controlled trial of kundalini yoga in mild cognitive impairment. Int Psychogeriatr 29, 1-11.

[22] Khalsa DS (2015) Stress, meditation, and Alzheimer's disease prevention: Where the evidence stands. J Alzheimers Dis 48, 1-12.

[23] Khalsa DS (2020) Mind-body medicine and the prevention of Alzheimer's disease. In Integrative Neurology, McBurney JW, Ruhoy IS, eds. Oxford University Press, New York, pp. 184-218.

[24] Koenig HG (2008) Concerns about measuring "spirituality" in research. J Nerv Ment Dis 196, 49-55.

[25] Pew Research Center (2014) Religion and public life. https://www.pewforum.org/2015/11/16/event-is-theamerican-public-becoming-less-religious.

[26] Lavretsky H (2010) Spirituality and aging. Agin Health 6 , 749-769.

[27] Houtman D, Aupers S (2007) The spiritual turn and the decline of tradition: The spread of post-Christian spirituality in 14 western countries, 1981-2000. J Sci Study Relig 46, 305-320.

[28] Yoga Alliance (2016) Yoga in America Study. https:// www.yogaalliance.org/Portals/0/2016\%20Yoga\%20in\% 20America\%20Study\%20RESULTS.pdf.

[29] Clarke TC, Barnes PM, Black LI, Stussman BJ, Nahin RL (2018) Use of yoga, meditation, and chiropractors among U.S. adults aged 18 and over. NCHS Data Brief 325, 1-8.

[30] Pargament KI, Mahoney A, Exline JJ, Jones JW, Shafranske EP (2013) Envisioning an integrative paradigm for the psychology of religion and spirituality. APA Handbook of Psychology, Religion, and Spirituality, Pargament KI, Exline JJ, Jones JW, eds. American Psychological Association (Vol. 1): Context, theory, and research (p. 3-19).

[31] Koenig HG, Büssing A (2010) The Duke University Religion Index (DUREL): A five-item measure for use in epidemiological studies. Religions 1, 78-85.

[32] Dyson J, Cobb M, Forman D (1997) The meaning of spirituality: A literature review. J Adv Nurs 6, 1183-1188.

[33] Fisher J (2016) Selecting the best version of SHALOM to assess spiritual well-being. Religions 7, 45.

[34] Fisher J (2010) Development and application of a spiritual well-being questionnaire called SHALOM. Religions $\mathbf{1}$, 105-121.

[35] Gomez R, Fisher J (2003) Personality and individual differences: Domains of spiritual well-being and development and validation of the spiritual well-being questionnaire. J Individ Differ 35, 1975-1991. 
[36] Kaufman Y, Anaki D, Binns M, Freedman M (2007) Spirituality, religious practice may slow progression of Alzheimer's disease. Neurology 68, 1509-1514.

[37] Zimmer Z, Jagger C, Chiu CT, Ofstedal MB, Rojo F, Saito $\mathrm{Y}$ (2016) Spirituality, religiosity, aging and health in global perspective: A review. SSM Popul Health 2, 373-381.

[38] Livingston G, Huntley J, Sommerlad A, Ames D, Ballard C, Banerjee S, Brayne C, Burns A, Cohen-Mansfield J, Cooper C, Costafreda SG, Dias A, Fox N, Gitlin LN, Howard R, Kales HC, Kivimäki M, Larson EB, Ogunniyi A, Orgeta V, Ritchie K, Rockwood K, Sampson EL, Samus Q, Schneider LS, Selbæk G, Teri L, Mukadam N (2020) Dementia prevention, intervention, and care: 2020 report of the Lancet Commission. Lancet 396, 413-446.

[39] Sapolsky R (1992) Stress, the Aging Brain and the Mechanisms of Neuron Death. Bradford, Cambridge.

[40] Wilson RS, Arnold SE, Schneider JA, Kelly JF, Tang Y, Bennett DA (2006) Chronic psychological distress and risk of Alzheimer's disease in old age. Neuroepidemiology 27, 143-153.

[41] Lupien SJ, McEwen BS, Gunnar MR, Heim C (2009) Effects of stress throughout the lifespan on the brain, behavior and cognition. Natl Rev Neurosci 10, 434-445.

[42] Hölzel BK, Carmody J, Evans KC, Hoge EA, Dusek JA, Morgan L, Pitman RK, Lazar SW (2010) Stress reduction correlates with structural changes in the amygdala. Soc Cogn Affect Neurosci 5, 11-17.

[43] MacLean CRK, Walton KG, Wenneberg SR, Levitsky DK, Mandarino JP, Waziri R, Hillis SL, Schneider RH (1997) Effects of the transcendental meditation program on adaptive mechanisms: Changes in hormone levels and responses to stress after 4 months of practice. Psychoneuroendocrinology 22, 277-295.

[44] Mohan A, Sharma R, Bijlani RL (2011) Effect of meditation on stress-induced changes in cognitive functions. $J$ Altern Complement Med 17, 207-212.

[45] Ruscio AM, Hallion LS, Lim CCW, Aguilar-Gaxiola S, Al-Hamzawi A, Alonso J, Andrade LH, Borges G, Bromet EJ, Bunting B, Caldas de Almeida JM, Demyttenaere K, Florescu S, de Girolamo G, Gureje O, Haro JM, He Y, Hinkov H, Hu C, de Jonge P, Karam EG, Lee S, Lepine JP, Levinson D, Mneimneh Z, Navarro-Mateu F, PosadaVilla J, Slade T, Stein DJ, Torres Y, Uda H, Wojtyniak B, Kessler RC, Chatterji S, Scott KM (2017) Cross-sectional comparison of the epidemiology of dsm-5 generalized anxiety disorder across the globe. JAMA Psychiatry 74, 465-475.

[46] Galea S, Merchant RM, Lurie N (2020) The mental health consequences of COVID-19 and physical distancing: The need for prevention and early intervention. JAMA Intern Med 180, 817-818.

[47] Ettman CK, Abdalla SM, Gregory H. Cohen GH, Sampson L, Vivier PM, Galea S (2020) Prevalence of depression symptoms in us adults before and during the COVID-19 pandemic. JAMA Netw Open 3, e2019686.

[48] Czeisler Mé, Lane RI, Petrosky E, Wiley JF, Christensen A, Njai R, Weaver MD, Rebecca Robbins R, Facer-Childs ER, Barger LK, Czeisler CA, Howard ME, Rajaratnam SMW (2020) Mental health, substance use, and suicidal ideation during the COVID-19 pandemic. MMWR Morb Mortal Wkly Rep 69, 1049-1057.

[49] Mayo Clinic Staff (2020) COVID-19 (coronavirus): Long-term effects. Mayo Clinic. https://www.mayoclinic. org/diseases-conditions/coronavirus/in-depth/coronavir us-long-term-effects/art-20490351.
[50] Del Rio C, Collins LF, Malani P (2020) Long-term health consequences of COVID-19. JAMA 324, 1723-1724.

[51] Koenig HG (2020) Maintaining health and well-being by putting faith into action during the COVID-19 pandemic. J Relig Health 59, 2205-2214.

[52] Hart CW, Koenig HG (2020) Religion and health during the COVID-19 pandemic. J Relig Health 59, 1141-1143.

[53] Clark C, Caldwell T, Power C, Stansfeld SA (2010) Does the influence of childhood adversity on psychopathology persist across the lifecourse? A 45-year prospective epidemiologic study. Ann Epidemiol 20, 385-94.

[54] REPRINT OF: Felitti VJ, Anda RF, Nordenberg D, Williamson DF, Spitz AM, Edwards V, Koss MP, Marks JS (2019) Relationship of childhood abuse and household dysfunction to many of the leading causes of death in adults: The adverse childhood experiences (ACE) study. Am J Prev Med 56, 774-786.

[55] Anda RF, Felitti VJ, Bremner JD, Walker JD, Whitfield C, Perry BD, Dube SR, Giles WH (2006) The enduring effects of abuse and related adverse experiences in childhood. A convergence of evidence from neurobiology and epidemiology. Eur Arch Psychiatry Clin Neurosci 256, 174-86.

[56] Mickley Steinmetz KR, Muscatell KA, Kensinger EA (2010) The effect of valence on young and older adults' attention in a rapid serial visual presentation task. Psychol Aging 25, 239-45.

[57] Jiang S, Postovit L, Cattaneo A, Binder EB, Aitchison KJ (2019) Epigenetic modifications in stress response genes associated with childhood trauma. Front Psychiatry 10, 808.

[58] Al Aboud NM, Shahid H, Jialal I (2020) Genetics, Epigenetic Mechanism. StatPearls Publishing, Treasure Island.

[59] Wang L, Koenig HG, He Z, Sun X, Al Shohaib S, Wang Z (2020) Religiosity and telomere length: Moderating effect of religiosity on the relationship between high-risk polymorphisms of the apolipoprotein E and TOMM40 gene and telomere length. J Appl Gerontol 39, 627-634.

[60] Lavretsky H, Epel ED, Siddarth P, Nazarian N, St. Cyr N, Khalsa DS, Lin J, Blackburn E, Irwin MR (2013) A pilot study of yogic meditation for family dementia caregivers with depressive symptoms: Effects on mental health, cognition, and telomerase activity. Int J Geriatr Psychiatry 28, 57-65.

[61] Innes KE, Selfe TK, Brundage K, Montgomery C, Wen S, Kandati S, Bowles H, Khalsa DS, Huysmans Z (2018) Effects of meditation and music-listening on blood biomarkers of cellular aging and Alzheimer's disease in adults with subjective cognitive decline: An exploratory randomized clinical trial. J Alzheimers Dis 66, 947-970.

[62] Kaliman P, Álvarez-López MJ, Cosín-Tomás M, Rosenkranz MA, Lutz A, Davidson RJ (2014) Rapid changes in histone deacetylases and inflammatory gene expression in expert meditators. Psychoneuroendocrinology 40, 96-107.

[63] Stein-Behrins BA, Sapolsky R (1992) Stress, glucocorticoids and aging. Aging Clin Exp Res 4, 197-210.

[64] McEwen B, Sapolsky RA (1992) Stress and cognitive function. Endocrine Rev 7, 284-301.

[65] Ryff CD, Friedman EM, Morozik JA, Tsenkova V (2012) Psychological resilience in adulthood and later life: Implications for health, Bert Hayslip, Jr, Ed. Annual Review of Gerontology and Geriatrics 32, 73-92.

[66] Innes KE, Selfe TK, Khalsa DS, Kandati S (2016) Effects of meditation versus music listening on perceived stress, 
mood, sleep, and quality of life in adults with early memory loss: A pilot randomized controlled trial. J Alzheimers Dis 52, 1277-98.

[67] Moss AS, Wintering N, Roggenkamp H, Khalsa DS, Waldman MR, Monti D, Newberg AB (2012) Effects of an 8-week meditation program on mood and anxiety in patients with memory loss. J Altern Compl Med 18, 48-53.

[68] Jacobs TL, Epel ES, Lin J, Blackburn EH, Wolkowitz OM, Bridwell DA, Zanesco AP, Aichele SR, Sahdra BK, MacLean KA, King BG, Shaver PR, Rosenberg EL, Ferrer E, Wallace BA, Saron CD (2011) Intensive meditation training, immune cell telomerase activity, and psychological mediators. Psychoneuroendocrinology 36, 664-681.

[69] Tyler J. VanderWeele TJ, Alexandra E. Shields AE (2016) Religiosity and telomere length: One step forward, one step back. Soc Sci Med 163, 176-178.

[70] Newberg AB, Wintering N, Khalsa DS, Roggenkamp H, Waldman RW (2010) Meditation effects on cognitive function and cerebral blood flow in subjects with memory loss: A preliminary study. J Alzheimers Dis 20, 517-526.

[71] Khalsa DS, Amen D, Hanks C, Money N, Newberg AN (2009) Cerebral blood flow changes during chanting meditation. Nucl Med Commun 30, 1-6.

[72] Albrecht D, Isenberg AL, Stradford J, Monreal T, Sagare A, Pachicano M, Sweeney M, Toga A, Zlokovic B, Chui H, Joe E, Schneider L, Conti P, Jann K, Pa J (2020) Associations between vascular function and tau pet are associated with global cognition and amyloid- $\beta$. J Neurosci 40, 85738586 .

[73] Newberg AB, Wintering N, Waldman MR, Amen D, Khalsa DS, Alavi A (2010) Cerebral blood flow differences between long-term meditators and non-meditators. Conscious Cogn 19, 899-905.

[74] MacDonald ME, Williams RJ, Rajashekar D, Stafford RB, Hanganu A, Sun H, Berman AJL, McCreary CR, Frayne R, Forkert ND, Pike GB (2020) Age-related differences in cerebral blood flow and cortical thickness with an application to age prediction. Neurobiol Aging $\mathbf{9 5}$, 131-142.

[75] Harrison TM, Weintraub S, Mesulama MM, Rogalski E (2012) Superior memory and higher cortical volumes in unusually successful cognitive aging. J Int Neuropsychol Soc 18, 1081-1085.

[76] MacLullich AM, Ferguson KJ, Wardlaw JM, Starr JM, Deary IJ, Seckl JR (2006) Smaller left anterior cingulate cortex volumes are associated with impaired hypothalamic-pituitary-adrenal axis regulation in healthy elderly men. J Clin Endocrinol Metab 91, 1591-1494.

[77] Hoenig M, Bischof G, Willscheid N, van Eimeren T, Drzezga A; Alzheimer's Disease Neuroimaging Initiative (2020) Resistance to tau and amyloid- $\beta$ pathology facilitates super-aging. J Nucl Med 61(Suppl 1), 20.

[78] Leech R, Sharp DJ (2013) The role of the posterior cingulate cortex in cognition and disease. Brain 137, 12-32.

[79] Newberg AB, Iversen $\mathbf{J}$ (2003) The neural basis of the complex mental task of meditation: Neurotransmitter and neurochemical considerations. Med Hypotheses 61, 282291.

[80] Streeter CC, Jensen JE, Perlmutter RM, Cabral HJ, Tian H, Terhune DB (2007) Yoga asana sessions increase brain GABA levels: A pilot study. J Altern Compl Med 13, 419426.

[81] Kljajevic V, Grothe MJ, Ewers M, Teipel S, Alzheimer's Disease Neuroimaging Initiative (2014) Distinct pattern of hypometabolism and atrophy in preclinical and prede- mentia Alzheimer's disease. Neurobiol Aging 35, 19731981.

[82] Nash JD, Newberg A (2013) Towards a unifying taxonomy and definition for meditation. Front Psychol 4, 806.

[83] Scheff SW, Neftner JH, Nelson PT (2014) Is synaptic loss a unique hallmark of Alzheimer's disease? Biochem Pharmacol 88, 517-528.

[84] Scheff SW, Price DA (2003) Synaptic pathology in Alzheimer's disease: A review of ultra structured studies. Neurobiol Aging 24, 1029-1046.

[85] Pei YA, Davies J, Zhang M, Zhang H (2020) The role of synaptic dysfunction in Alzheimer's disease. J Alzheimers Dis 76, 49-62.

[86] Khalsa DS (2001) Alzheimer's disease. In Integrative Medicine, Rakel D, ed. Elsevier Saunders.

[87] Black DS, Cole SW, Irwin MR, Breen E, St Cyr NM, Nazarian N, Khalsa DS, Lavretsky H (2013) Yogic meditation reverses NF-kB and IRF-related transcriptome dynamics in leukocytes of family dementia caregivers in a randomized controlled trial. Psychoneuroendocrinology 38, 348-355.

[88] Yang H, Leaver AM, Siddarth P, Paholpak P, Ercoli L, St. Cyr NM, Eyre HA, Narr KL, Khalsa DS, Lavretsky H (2016) Neurochemical and neuroanatomical plasticity following memory training and yoga interventions in older adults with mild cognitive impairment. Front Aging Neurosci $\mathbf{8}, 277$.

[89] Eyre HA, Acevedo B, Hongyu Y, Prabha S, Kathleen VD, Ercoli L, Leaver AM, St Cyr N, Narr K, Baune BT, Khalsa DS, Lavretsky H (2016) Changes in neural connectivity and memory following a yoga intervention for older adults: A pilot study. J Alzheimers Dis 52, 673-684.

[90] Innes, KE, Selfe TK, Khalsa DS, Kandati S (2017) Meditation and music improve memory and cognitive function in adults with subjective cognitive decline: A pilot randomized controlled trial. J Alzheimers Dis 56, 899-916.

[91] Innes KE, Selfe TK, Brown C, Rose KM, ThompsonHeisterman A (2012) The effects of meditation on perceived stress and related indices of psychological status and sympathetic activation in persons with Alzheimer's disease and their caregivers: A pilot study. Evid Based Complement Altern Med 2012, 927509.

[92] Lavretsky H (2014) Resilience and aging: Research and practice. John Hopkins University Press, Baltimore.

[93] Park C (2005) Religion as a meaning-making framework in coping with life stress. J Soc Issues 61, 707-729.

[94] Schuurmans-Stekhoven JB (2018) Conviction, character and coping: Religiosity and personality are both uniquely associated with optimism and positive reappraising. Ment Health Relig Cult 21, 763-779.

[95] Yang H, Ma J (2020) How an epidemic outbreak impacts happiness: Factors that worsen (vs. protect) emotional well-being during the coronavirus pandemic. Psychiatry Res 289, 113045.

[96] Sheardova K, Nedelska Z, Sumec R, Marciniak R, Belaskova S, Lerch O, Hort J (2018) The effect of spiritual well-being (transcendental and non-transcendental domain) on regional brain atrophy in non-demented subjects with memory complaints: 3 -year follow up data from the Czech brain aging study. Alzheimers Dement 14, 587588.

[97] Koenig HG (2001) Religion, spirituality, and medicine: How are they related and what does it mean? Mayo Clinic Proc 76, 1189-1191. 
[98] Paz Mosqueiro B, Marcelo P Fleck MP, Neusa Sica da Rocha N (2019) Increased levels of brain-derived neurotrophic factor are associated with high intrinsic religiosity among depressed inpatients. Front Psychiatry 10, 671.

[99] Zhang W (2010) Religious participation, gender differences, and cognitive impairment among the oldest-old in China. J Aging Res 2010, 160294.

[100] Fung AWT, Lam LCW (2013) Spiritual activity is associated with better cognitive function in old age. East Asian Arch Psychiatry 23, 102-107.

[101] Lee BY, Newberg AB (2010) The interaction of religion and health. In Weil integrative medicine library. Integrative Psychiatry, Monti DA, Beitman BD, eds. Oxford University Press, pp. 408-444.

[102] Rath T, Harter J (2010) Well being: The five essential elements. Gallup Press, New York.

[103] Boyle PA, Buchman AS, Wilson RS, Barnes LL, Bennett DA (2010) Effect of a purpose in life on incident Alzheimer disease and mild cognitive impairment in community-dwelling older persons. Arch Gen Psychiatry 67, 304-310.

[104] Ryff CD (1989) Happiness is everything, or is it? Explorations on the meaning of psychological well-being. J Pers Soc Psychol 57, 1069-1081.

[105] Ryff CD, Keyes CLM (1995) The structure of psychological well-being revisited. J Pers Soc Psychol 69, 719-727.

[106] Khalsa DS, Perry G (2017) The four pillars of Alzheimer's prevention. Cerebrum 2017, 03-17.

[107] Robitschek C, Ashton MW, Spering CC, Geiger N, Byers D, Schotts GC, Thoen MA (2012) Development and psychometric evaluation of the personal growth initiative scale-II. J Couns Psychol 59, 274-287.

[108] Ryff CD, Singer BH, Dienberg Love G (2004) Positive health: Connecting well-being with biology. Philos Trans $R$ Soc Lond B Biol Sci 359, 1383-1394.

[109] Musich S, Wang SS, Kraemer S, Hawkins K, Wicker E (2018) Purpose in life and positive health outcomes among older adults. Popul Health Manag 21, 139-147.

[110] Yu L, Boyle PA, Robert S Wilson RS, Levine SR, Schneider JA, Bennett DA (2015) Purpose in life and cerebral infarcts in community-dwelling older people. Stroke 46, 1071-1076.

[111] Kim ES, Sun JK, Park N, Kubzansky LD, Peterson C (2013) Purpose in life and reduced risk of myocardial infarction among older U.S. adults with coronary heart disease: A two-year follow-up. J Behav Med 36, 124-133.

[112] Kim ES, Sun JK, Park N, Peterson C (2013) Purpose in life and reduced incidence of stroke in older adults: 'the health and retirement study'. J Psychosom Res 74, 427-432.

[113] James BD, Boyle PA, Buchman AS, Bennett DA (2011) Relation of late-life social activity with incident disability among community-dwelling older adults. J Gerontol 66A, 467-473.

[114] Kim ES, Strecher VJ, Ryff CD (2014) Purpose in life and use of preventive health care services. Proc Natl Acad Sci U S A 111, 16331-16336.

[115] Boyle PA, Barnes LL, Buchman AS, Bennett DA (2009) Purpose in life is associated with mortality among community-dwelling older persons. Psychosom Med 71, 574-579.

[116] Lewis NA, Turiano NA, Payne BR, Hill PL (2017) Purpose in life and cognitive functioning in adulthood. Aging Neuropsychol Cogn 24, 662-671.
[117] Ryff CD, Dienberg Love G, Urry HL, Muller D, Rosenkranz MA, Friedman EM, Davidson RJ, Singer B (2006) Psychological well-being and ill-being: Do they have distinct or mirrored biological correlates? Psychother Psychosom 75, 85-95.

[118] Boyle PA, Buchman AS, Wilson RS, Yu L, Schneider JA, Bennett DA (2012) Effect of purpose in life on the relation between Alzheimer disease pathologic changes on cognitive function in advanced age. Arch Gen Psychiatry 69, 499-505.

[119] Chen ST, Siddarrth P, Saito NY, Rueda F, Haight T, Ercoli LM, Miller KJ, Lavretsky H, Barrio JR, Bookheimer SY, Small GW, Merrill DA (2014) Psychological well-being and regional brain amyloid- $\beta$ and tau in mild cognitive impairment. Am J Geriatr Psychiatry 22, 362-369.

[120] Hummer RA, Rogers RG, Nam CB, Ellison CG (1999) Religious involvement and U.S. adult mortality. Demography 36, 273-85.

[121] Hill PL, Turiano NA (2014) Purpose in life as a predictor of mortality across adulthood. Psychol Sci 25, 1482-1486.

[122] Ware B (2012) The top five regrets of the dying. Hay House Inc., Carlsbad.

[123] Quinzi F, Berchicci M, Bianco V, Filippo GD, Perri RL, Russo FD (2020) The role of cognitive reserve on prefrontal and premotor cortical activity in visuo-motor response tasks in healthy old adults. Neurobiol Aging 94, 185-195.

[124] Schoormans D, Nyklíček I (2011) Mindfulness and psychologic well-being: Are they related to type of meditation technique practiced? J Altern Complement Med 17, 629634.

[125] Salsman JM, Brown TL, Brechting EH, Carlson CR (2005) The link between religion and spirituality and psychological adjustment: The mediating role of optimism and social support. Pers Soc Psychol Rev 31, 522-35.

[126] Ryff C, Friedman E, Fuller-Rowell T, Love G, Miyamoto Y, Morozink J, Radler B, Tsenkova V (2012) Varieties of resilience in MIDUS. Soc Personal Psychol Compass 1, 792-806.

[127] Ahlberg AC, Ljung T, Rosmond R, McEwen B, Holm G, Åkesson HO, Björntorp P (2002) Depression and anxiety symptoms in relation to anthropometry and metabolism in men. Psychiatry Res 112, 101-110.

[128] Landén M, Baghaei F, Rosmond R, Holm G, Björntorp P, Eriksson E (2004) Dyslipidemia and high waist-hip ratio in women with self-reported social anxiety. Psychoneuroendocrinology 29, 1037-1046.

[129] Räikkönen K, Matthews KA, Kuller LH, Reiber C, Bunker CH (1999) Anger, hostility, and visceral adipose tissue in healthy postmenopausal women. Metabolism 48, 1146-51.

[130] Post SG (2014) Is ultimate reality unlimited love? Templeton Press, West Conshohocken.

[131] Shany-Ur T, Lin N, Rosen HJ, Sollberger M, Miller BL, Rankin KP (2014) Self-awareness in neurodegenerative disease relies on neural structures mediating reward-driven attention. Brain 137, 2368-2381.

[132] Perez-Bret E, Altisent R, Rocafort J (2016) Definition of compassion in healthcare: A systematic literature review. Int J Palliat Nur 22, 599-606.

[133] Dewar B, Pullin S, Tocheris R (2011) Valuing compassion through definition and measurement. Nurs Manag (Harrow) 17, 32-7.

[134] Torralba Rosello F (2000) Constructos eticos del cuidar. Enferm Intensiva 11, 136-41. 
[135] Nouwen HJM, McNeill DP, Morrison DA (1982) Compassion: A reflection on the Christian life. Image Books Doubleday, New York.

[136] Jimenez A, Triana M, Washburn J (2002) Compasion y salud. Rev Filosofia Moral Politica 27, 211-23.

[137] Ryff CD, Singer BH (2008) Know thyself and become what you are: A eudaimonic approach to psychological well-being. J Happiness Stud 9, 13-39.

[138] Post S (2003) Unlimited love. Templeton Press, Radnor.

[139] Kimble MA (2002) Beyond the biomedical paradigm: Generating a spiritual vision of ageing. J Relig Gerontol 12, 31-41.

[140] Montero-Marin J, Perez-Yus MC, Cebolla A, Soler J, Demarzo M, Garcia-Campayo J (2019) Religiosity and meditation practice: Exploring their explanatory power on psychological adjustment. Front Psychol 10, 630.

[141] Newberg AB (2010) Principles of Neurotheology. Ashgate Publishing Ltd, Surrey.

[142] Yaden DB, Haidt J, Hood RW, Vago DR, Newberg AB (2017) The varieties of self-transcendent experience. Rev Gen Psychol 21, 143-160.

[143] Beauregard M, O'Leary D (2007) The spiritual brain: A neuroscientist's case for the existence of the soul. HarperOne/HarperCollins, New York.

[144] Fingelkurts AA, Fingelkurts, AA (2009) Is our brain hardwired to produce God, or is our brain hardwired to perceive God? A systematic review on the role of the brain in mediating religious experience. Cogn Process 10, 293-326.

[145] Newberg A, Wintering NA, Morgan D, Waldman MR (2006) The measurement of regional cerebral blood flow during glossolalia: A preliminary SPECT study. Psychiatry Res Neuroimaging 148, 67-71.

[146] Garrison KA, Scheinost D, Constable RT, Brewer JA (2014) BOLD signal and functional connectivity associated with loving kindness meditation. Brain Behav 4, 337-347.
[147] Newberg AB (2014) The neuroscientific study of spiritual practices. Jefferson Myrna Brind Center of Integrative Faculty Papers, Paper 14.

[148] Newberg AB, Serruya M, Wintering N, Moss AS, Reibel D, Monti DA (2014) Meditation and neurodegenerative diseases. Ann NY Acad Sci 1307, 112-123.

[149] Newberg AB (2015) The neurotheology link: An intersection between spirituality and health. Altern Complement Ther 21, 13-17.

[150] Isaacson RS, Ganzer CA, Hristov H, Hackett K, Caesar E, Cohen R, Kachko R, Meléndez-Cabrero J, Rahman A, Scheyer O, Hwang MJ, Berkowitz C, Hendrix S, Mureb M, Schelke MW, Mosconi L, Seifan A, Krikorian R (2018) The clinical practice of risk reduction for Alzheimer's disease: A precision medicine approach. Alzheimers Dement 14, 1663-1673.

[151] Solomon A, Mangialasche F, Richard E, Andrieu S, Bennett DA, Breteler M, Fratiglioni L, Hooshmand B, Khachaturian AS, Schneider LS, Skoog I, Kivipelto M (2014) Advances in the prevention of Alzheimer's disease and dementia. J Intern Med 275, 229-250.

[152] Lourida I, Hannon E, Littlejohns TJ, Langa KM, Hyppönen E, Kuzma E, Llewellyn DJ (2019) Association of lifestyle and genetic risk with incidence of dementia. JAMA 322, 430-437.

[153] Innes KE, Selfe TK (2014) Meditation as a therapeutic intervention for adults at risk for Alzheimer's disease potential benefits and underlying mechanisms. Front Psychiatry $\mathbf{5}, 40$.

[154] Nelson-Becker H, Nakashima M, Canda ER (2007) Spiritual assessment in aging: A framework for clinicians. $J$ Gerontol Soc Work 48, 331-47. 